\title{
Religiously Motivated Political and Religious Nationalism of Israel-Palestine conflict
}

\author{
Nabih Maged Abdelhakam \\ Ain Shams University, Cairo, Egypt \\ Mage_abul1987@gmail.com
}

\begin{abstract}
Religion and politics exist on a continuum with varying costs. The dominance of one over the other has consequences for the safety of people, whichever domain has the power. If religion is empowered absolutely, it is abused in the legitimization it gives to violence. If politics is empowered absolutely, the sacred space of human history is denied the ability to flourish and sustain human communities. Yet the tension between the two facets of human society is not one where either will fully can walk away from the temptation of power, whether the opportunity to control is absolute or not.
\end{abstract}

Keyword: Religiously Motivated; Religious Nationalism; Israel-Palestine conflict

\section{Introduction}

Hannah Arendt brilliantly chronicled in her study of totalitarianism the way that political regimes who define and control the existence of their subjects in absolute utilitarian ways come to circumvent the capacity of those subjects to critique state power, as well as the means by which they can then meaningfully name what that power is.

Similarly, Marc Ellis's writing on the remnants of the prophetic Jewish tradition after the events of 1948 and 1967 show that, like Christians have learned, there is something wrong with a religious tradition that comes to see itself through the eyes of the state. He suggests that in this lesson, Jews need to atone for the sins committed against Palestinians in the name of Judaism and the Zionist vision of a "secure" homeland, just as Christians have had to atone for the sins committed against Jews in the name of the Trinitarian God and ontological assumptions about the desirability of a "pure" or "efficient" culture.

In this analysis, there are similarities between Arabs' and Jews' national aspirations and the facility of a narrow definition of political identity in the enterprise of building a national culture. Neither form of nationalism has seen fit to include reconciliation or voluntarism toward the enemy (the ethno-cultural "Other"), as such is not expedient to the goals of nation-building. The questions 
that liberation theology poses for persons of good-will thus have a broader scope, which has been shown to be a historically significant boundary at which a religion is called to reconsider its purposes as much as a government is called to reconsider its treatment of its members. This twofold critique that grows out of a theological study of one's socio-political context, and the injustices therein, lead one to ask "liberation from what?" and "change for whom?" Here the gaze of the Other is turned back on the Self in the interests of human society as well as the continuity of religious belief in the fragmented world of today.

While sociologists may find that imagined communities are strengthened by "in group" versus "out group" identities, the question of value is the sustainability of those communities-be they "strong" or "weak" according to statistical matrices. One need not dispute the fact that a strong sense of belief and behavior are part of what create the sense of certainty which leads many around the world to convert to Islam, however few who know the diversity of views and tradition of contested authority within Islam since its seventh-century founding would consider it proof that truth is found in institutional strength alone.

\section{Discussion}

To understand the conflict, it has been therefore necessary to take a multi-dimensional, multi-disciplinary approach that allows the identities at play to themselves be questioned, as much as ideology and historical narrative they convey.

In today's context, it is often from one's own that one is exiled, as intellectuals and theologians reject traditions whose categories are incompatible with the fragmented and complex world in which they live, or who seek a "good" more broad than self- interest would allow. There are many boundaries which can divide people, yet the overlapping identities of both Jews and Palestinians is not a semantic or superficial consideration. In negotiating religion and politics within the twentieth and twenty- first centuries, it is clear that only authenticity provides a foundation for sustainable alternatives even if that means being exiled from one's own.

This ethical means of defining "liberation" may appear naïve to some, who say that whatever Palestinians may say, what they mean is revolution and an end to the Israeli state. Such people would silence Arab Israelis and much as the worldwide leadership of the Palestinian National Council, suggesting that the Palestinian establishment does not reflect the reality of who Palestine is today. Such hawkish critics point to the actions of the armed opposition groups, especially those whose religious context suggests an easy antithesis to Jewish security. Palestinian identity is thus codified in the Western gaze, and flattened to a singular and singularly undependable factor around which transnational, economic, and military negotiations must be made. In short, it is a thorn in the side of the civilized world.

It is silenced at diplomatic levels despite its dependence on the Arab and international communities to support its desire for self-determination and a better future. For example, U.N. Resolutions 242 and 338 do not deal with the Palestinians as a nation, but only the burden Palestinian refugees place on their Arab hosts (Ashrawi, 1992). 
Their analysis is, moreover, derided by its critics as too pro-Palestinian (Shainin, 2002). Edward Said sets up an understanding of human relations where the problem is one of representation, and as such it plagues intellectuals of all stripes with a creative if irresolvable tension between theory and action.

What remains politically is for government to act only in so far as it enables a fair foundation in which a just peace might grow organically, or from within, and with a courageous commitment to the democratic capacity of its members. In the intellectual climate of the twenty-first century, this puts a responsibility — not just a right — on citizens to maintain an idealistic pragmatism — both radically hopeful and skeptically wise vis-à-vis the context and nature of power. This is a complex task which Hannah Arendt argues involves at its heart, the capacity to reason and judge fairly between self and other. As she argued in her essay, "The Crisis in Culture,"

The power of judgment rests on a potential agreement with others, and the thinking process which is active in judging something is not, like the thought process of pure reasoning, a dialogue between me and myself, but finds itself always and primarily, even if I am quite alone in making up my mind, in an anticipated communication with others with whom I know I must finally come to some agreement. And this enlarged way of thinking, which as judgment knows how to transcend its individual limitations, cannot function in strict isolation or solitude; it needs the presence of others "in whose place" it must think, whose perspective it must take into consideration, and without whom it never has the opportunity to operate at all (Arendt, 1992).

Lévinas reminds one of a broader, "universal" dimension of human relations toward the problem of power that does not take lightly the excuses of historical context, yet he-like Wiesel, Walzer, Ozick, and others-falls short of demanding the same universal treatment toward Palestinians on which Jews have founded their post-Holocaust identity, when the two clash. British professor of cultural history Howard Caygill put his finger on the tension that Lévinas could satisfy: "The difficulty arises when political logic would tend towards greater peace and justice, while considerations of holy history would encourage attitudes and behaviour that provoke war." Caygill, 2002).

While Lévinas draws the reader back to the Greco-Roman foundations of Western society in a way similar to Hannah Arendt and other multi-disciplinary philosophers, arguing that religion provides for humanity a sense of universality and its gravity within history, Caygill's close analysis of his political thought reveals a incongruent dissonance between his ethics, founded on a universal call for justice, and his politics, founded on the Jews' "holy" obligation to survive at any cost. One is confronted by the fact that, nevertheless, and contrary to the belief (rhetorical or not) that God is dead and history met its end after the Holocaust, intellectual life has continued into the twenty-first century.

Disabused of her presumptions, the intellectual must today put herself squarely within the realm of the non-intellectual-the "organic" intellectual in Italian theorist Antonio Gramsci's terms - and imagine a new life of the Mind and Heart that is relevant in this fractured, poststructural world in which one is at once aware of the past and future. Jewish writings on the prophetic tradition demonstrate that Western intellectual thought has evolved through time yet 
remains focused on its origins and foundations. However, they also show the difficulty in seeing outside oneself, juxtaposed as they are against the bitter realities that arise when one does not. In doing so, they underscore the need for community and a sense of solidarity beyond the coincidence of geography and the privilege of identity.

In the space between prophesy, conjecture and disinterest, how might justice be done and for whom ought judgment to exist, as Arendt defined it above? Consideration of others' suffering is for many the essence of Judaism, yet there is an increasing consensus that Israeli policies are an exception to that rule - and thus are more than just blind- spot in contemporary Jewish commentary or Western intellectual thought, but rather are its very downfall. If belief in God is difficult after Auschwitz, the writings of Ellis and Ateek show that belief in the authenticity of the rabbinical and prophetic traditions within Judaism - no less than the authenticity of the contemporary Christian witness - is impossible if they are unable to search their own depths and answer for the injustice they have sought, committed, and ignored (Prager ,1975). Whatever the justification of selfsufficiency and suspicion or the basis for the exclusion of non-Jews, the lived reality of Palestinians forces one to reconsider his or her role in establishing a just peace in today's political economy.

Are these being foolhardy concerns? They address the matrix of factors which contribute to differentiate identity and justify violence. They challenge the imbalance of power and the expectation that one people's nationalism is better or more worthy than another's within the modern era. Separate from the bankrupt and stymied pattern of diplomatic resolutions and theoretical projections, a future is conceivable for Jews, Muslims, and Christians in Israel and Palestine that would serve as a foundation for renewal and learning, reconciliation and self-examination.

The brilliance of liberal democracy, as it has emerged in the American enterprise through the malleable but constitutionally distinct view of statehood and all things religious, is due in large part to its safeguarding of religious vitality and personal voluntarism. Although Christianity continues to pervade American culture, it is not procedurally protected or privileged by law. Judaism, however, faces a much different arrangement with the state of Israel, a self-professed "Jewish," "democratic" state. Political theorists have had to turn circles to find a definition of democracy that defies both the norm and the practice of European liberalism, and that allows the privileging of one ethnic and religious group over others to neither undo itself or the entire project of statehood.

Israeli sociologist Moshe Zuckerman makes an intriguing claim about the effect of the Israeli-Palestinian conflict that seems to have implications for American social stratification too (John Bunzl, 2002), Zuckerman describes the direction of Israeli political culture as dependent on a "false consciousness" whereby Israeli selfhood has been based on a manipulation of guilt and anxiety toward others - namely, Holocaust survivors, indigenous Palestinians and ultra-Orthodox Jews, or the three largest "out-groups" of Israeli society. From a secular, sociological perspective, he, like Ellis, claims that the only way to overcome the marginalization of these out-groups is a radical de-Zionization of Israeli policy and political procedure. His vision not only collapses the fractures within Israeli society and the Jewish community worldwide, so that non-observant, nonAshkenazi, and/or non-American Jews are accepted fully within a new image of Israel. It also enables a foundation for non-Jews-whatever their specific ethnic or religious origins-to 
participate in the flourishing of the state of Israel as equals and non-outsiders. This begs the question, why would a non-Jew want to live in Israel and be Israeli?

This is the project of a democracy - to provide equal opportunity to all citizens. It is the natural, if contradictory, end-product of a national struggle. Yet when Israelis talk of peace they still mean the cessation of open violence and the security of their own people-Jews-from outside attacks by non-Jews. When Palestinians talk of peace, they mean procedural justice, food security, security from midnight raids, cessation of helicopter reprisals, and an end to occupation - in other words, the cessation of open violence and the "security" of their people from outside attacks by non-Palestinians. Israelis demand peace before Palestinians can have the political recognition they crave, yet Palestinians are expected to achieve democracy before they have freedom and national sovereignty. Yet both people's talk of "peace" is limited to the outsider. At a point in the not-sodistant future, if and when occupation ends and Palestinian national aspirations achieve viable statehood, the conversation must turn inward toward internal social cohesion and reconciliation with the "alien within thy gates" (Borowitz, 1990).

On the American side, it must be asked at what price the prevalent Christian paradigm continues in America even outside of de jure procedures and who it is that actually suffers its consequences. Evangelical and fundamentalist concerns over the secularization and anti-Christian bias of American society are dubious in so far as the pro-Israeli bias of American foreign policy makers and the growing anti-Muslim bias of the general American public is fostered by Christian writers and theologians. It is most easily argued that American Christians have an obligation to widen their purview to include the plight of Eastern, Palestinian Christians in their cannon of suffering and persecution-however, as demonstrated above with the twentieth century trajectory of Judaism in Europe, America and the Middle East, such would only further evade the true dimension of change needed. Is the problem in the application of Christianity rather than its presence, or must American culture go through a radical and total de-Christianization process before justice can be sought for Muslims and non-American Jews and Christians alike?

The project of moral judgment has no boundaries, neither territorial nor historical, and must logically begin with one's self, before another. That is to say that "liberation," as we have used it, is a concept relative to its opposite, that which is "oppressive." Globalization has only furthered the boundaries of these terms and the stakes for which the debate continues. Have the people and aspirations of Israel and Palestine fallen through the cracks of modern liberalism, or is their experience, like that of the Balkans, the hidden story of liberalism? The subjective experience of Jews, like Christians, must never be allowed silence moral judgment—nor for Muslims, as clerical orders for suicide bombings among radical factions indeed do. However, many Israelisparticularly the observant, religious community - do not see Israel as oppressive at all, but rather as a state that fulfills Jews" covenantal obligation "to live as a community whose life was structured by God's Torah" (Ibid). It is little wonder that dissenting Jews shift the burden of justice from the people to the tradition. Is the Covenant, as it has been handed down from ancient times, amenable to the knowledge gained from life in exile, as outsiders? Does the story of righteousness - of the Jewish Covenant—rightfully end with Jews? As Ellis asks, do today's "Jews"- the Palestiniansmatter to the Jewish Covenant let alone the American constitution? 
Relationships are imbued with unpredictability and concealment, because of the internal dynamics and diversity of human behavior as much as the only partial external access one has to the experiences of others, even those with whom one is intimate. Christian groups respond in diverse doctrinal and social ways to the problem of political power and the use of violence, as they do to the call for pacifism, or an active resistance to the impulse of war. In the context of Israel and Palestine, the most interesting and bifurcation is within each community, rather than between them. Palestinian Christians stand at a unique crossroads-perhaps better termed a precipice-in witnesses both of Palestine and Christianity. The struggle they face is not how to name the problem but how to respond to the "immediate evil" they and their parishioners face daily while neither inflaming the political tensions with Israel nor neglecting the spiritual needs of the people and their material duties as church administrators. (Nussbaum ,1999).

She finds in Woolfe's portrait of the Ramsay family a thought-provoking insight into broader society and world events. In particular, it is through the free-verse of the character's inner thoughts that the reader finds a foothold for compassion and can imagine change - that is, it is the characters' self-perception and memory as much as others' superficial opinions of their characters which allows the reader to understand and accommodate the details of each other's lives and of their environment and imagine a way for their paths to harmonize and for forgiveness to prevail (Woolf, 1927).

From the beginning, each encounter is filled with possibilities which blossom and fade through dialogue, inaction, and distraction, and as the observant reader, we can see signals of future events even before they do, even though such are often unheeded or misread by the characters themselves.

Such a narrative exposition on the human mind and its ability to understand beyond itself directly exemplifies the enterprise I see necessary for sustainable and wise change in IsraelPalestine - that is, a future worth fighting for. Even "people of goodwill," as Nussbaum says, could easily disengage or throw up their hands in frustration, lamenting the status quo and clinging to their resentment of the hornet's nest that they suspect in the other's mind, so to speak. Moral judgment, however, cannot stop so short. It is only with conscientious attention to the people and environment around us, and a determinedly broad perspective on social justice, which will enable Jews, Christians, and Muslims to develop and implement the prophetic spirituality needed to critique society and to move forward. Divorce is not an option for the people of Israel and Palestine, for even once an independent Palestinian state is established there will always be some degree of overlap, from labor resources to airspace rights to religious sites and theological commentary.

As each national and religious group comes to see the contradictions of its own identity it is abler to acknowledge the good within its supposed enemy-be that secular versus religious Jews, Muslim versus Christian Palestinians, or Palestinians versus Israelis. Moreover, each group must recognize the way that - for others - the extreme views within its group often come to represent something essential about its identity (Javadikouchaksaraei et al., 2016). This is why those best poised to challenge the ideology and interests behind atrocity are "the better angels" within that group-not outside voices. Can America put pressure on Israel to change its policies of 
extrajudicial assassination, military incursions, closure, and so on? Can pressure come from the electorate and the public, so that those policies are not to be reinstated elsewhere?

Two months after the United States declared war in Iraq in March 2003-long before the fall-out of its miscalculations and abuses against political prisoners became common discourse in America-American social historian and public intellectual Cornel West stood before a packed hotel ballroom in downtown Washington, DC and challenged the United States' rationale for its "preemptive" mobilization. He argued that the government's reasoning was short-sighted and illconceived, and that its effect was, in part, cover and legitimization for Israel's claims of "preemptive" security through unprovoked house demolitions and illegal incursions into Palestinian territory. West argued that the means by which the U.S. sought to eradicate terrorism were precisely those which would inhibit democracy from growing internally, or naturally, and that this would thereby engender the very instability that it attempted to circumvent.

West's critique of this preemptive foreign policy—which is not so new if one considers Israel's methodology of containing Palestinian resentment since the first intifada almost two decades ago - outlined three forms of courage necessary to ground any project of social transformation: 1) the Socratic courage to ask painful questions about oneself, one's society, and the surrounding world; 2) the prophetic courage to exercise compassion and to listen to suffering as truth; and 3) the democratic courage in which dogma and ideology are held accountable to real life and lived experiences (Nussbaum, 1997).

The audience to whom West addressed his critique was a gathering of Jews, Christians, Muslims, Buddhists, and others who identified themselves as both "pro-Israeli and pro-Palestinian. They too saw the American war as headed in the direction of the entrenched violence and power imbalance between Israelis and Palestinians; similarly, they too found the aggression and political rhetoric of both conflicts the result of a deeper spiritual malaise (Lerner, 2003).

West spoke from within the same prophetic tradition grounding the theologies of liberation that we have reviewed in this thesis, including the writings of Naim Ateek, Marc Ellis, Gustavo Gutierrez, Rosemary Radford Ruether, and others. Like these writers' call to reconceive the Scriptures on behalf of the poor and the marginalized, West's three-fold challenge attempts to reconceive - that is, to re-sensitize and de-polarize - political negotiation in situations of conflict, one person at a time. He argues this can be done through critical thought, inclusive compassion, and a democratic spirit (Robinson, 2002).

The conflict in Israel-Palestine obviously relates to the American body politic in so far as America supports Israel financially. It seems that globalized economies mean simply an extension of economic dependency - from the Palestinians on Israel's economy to Israel's on the American economy, even to America's dependency on Saudi Arabia's economy in terms of our disproportionate oil production and consumption patterns. If the conflict's core is indeed political and economic, rather than religious or ethnic, what alternative paradigm for change might America bring to the table and/or impose upon the parties just as Britain did the idea of partition in 1948 ? 
It is not enough to assert that genuine reconciliation between the political/social groups will arise only when it is mutually implemented, as is the premise of the Bush Administration's "Road Map" (Bishara, 2003).

\section{Conclusion}

We have addressed how structural parity through statehood and its corollary, citizenship, is only one dimension of the project toward a just peace between Israelis and Palestinians. The ideology and entrenched interests that legitimate atrocity must be challenged if change is to occurthis is true for the extreme wings of both Palestinian and Israeli society. The manipulation of the public good through ideology, language, and symbolic artifacts - including holiday rituals, national myths, architecture, even geography itself - is an alienating and ultimately bad policy for unity within a national group, let alone peace with its neighbors. Such manipulation - for example using religious language to augment political legitimacy, as Sharon, Arafat, and many others have been known to do-is unsustainable unless the values embodied in that language are put into practice. The inclusive vision of the Israeli Declaration of Independence does not remove the reality of racism from Israeli society-instead it belies the authenticity of democracy in Israel. Poverty, ignorance, and moral differentiation between ethnic or religious groups must be attacked if rhetoric and the status quo are to give way to transparency and authentic reconciliation.

\section{References}

Arendt, Hannah. "The Crisis in Culture," Between Past and Future: Six Exercises in Political Thought (New York: Routledge, 1992), 220-21.

Ashrawi, Hanan. "The Palestinian Reality," in Faith and the Intifada: Palestinian Christian Voices, ed. Naim S. Ateek, Marc H.Ellis, and Rosemary Radford Ruether (Maryknoll, NY: Orbis Books, 1992), 13.

Bishara, Azmi. in a speech to the St. Alban's Episcopalian Church community, Washington, DC (May 2003).

Borowitz, Eugene. Exploring Jewish Ethics: Papers on Covenant Responsibility (Detroit, MI: Wayne State University Press, 1990), 129.

Bunzl, John. "Towards a Critical Analysis of Israeli Political Culture," in Psychoanalysis, Identity and Ideology: Critical Essays on the Israel/Palestine Case (Boston, MA: Kluwer Academic Publishers, 2002), 59-70.

Carey, Roane and Shainin, Jonathan. eds., The Other Israel: Voices of Refusal and Dissent, foreword by Tom Segev and intro by Anthony Lewis (NY: The New Press, 2002), 123-150.

Caygill, Howard. Lévinas and the Political (London: Routledge, 2002), 161.

Javadikouchaksaraei, M.*, Bustami, M. R. and Farouk, A. F. A., The rise of Jewish religious nationalism and Israeli approach to the Palestinian conflict, Pertanika Journal of Social Sciences \& Humanities (JSSH), 24 (1), 311-330, (2016). 
Lerner, Michael. Healing Israel/Palestine: A Path to Peace and Reconciliation (San Francisco, CA: Tikkun Books, 2003).

Nussbaum, artha C. Sex and Social Justice (NY: Oxford University Press, 1999), 355-373.

Nussbaum, Martha. "world citizens" through public action and education, in her Cultivating Humanity: A Classical Defence of Reform in Liberal Education (Cambridge, MA: Harvard University Press, 1997), 9-10.

Prager, Dennis \& Telushkin, Joseph. Eight Questions People Ask About Judaism (Whitestone, NY: Tze Ulmad Press, 1975), 207.

Robinson, George. Essential Judaism: A Complete Guide to Beliefs, Customs and Rituals (NY: Pocket Books, 2002), 243.

Woolf, Virginia. To the Lighthouse, with foreword by Eudora Welty (NY: Harcourt, Inc., 1927; 1981), ix.

\section{Copyrights}

Copyright for this article is retained by the author(s), with first publication rights granted to the journal.

This is an open-access article distributed under the terms and conditions of the Creative Commons Attribution license (http://creativecommons.org/licenses/by/4.0/). 